\title{
Brevinema andersonii gen. nov., sp. nov., an Infectious Spirochete Isolated from the Short-Tailed Shrew (Blarina brevicauda) and the White-Footed Mouse (Peromyscus leucopus)
}

\author{
D. L. DEFOSSE, ${ }^{1 *}$ R. C. JOHNSON, ${ }^{1}$ B. J. PASTER, ${ }^{2}$ F. E. DEWHIRST, ${ }^{2}$ AND G. J. FRASER ${ }^{2}$ \\ Department of Microbiology, University of Minnesota, Minneapolis Minnesota 55455, ${ }^{1}$ \\ and Forsyth Dental Center, Boston, Massachusetts $02115^{2}$
}

\begin{abstract}
A spirochete which infects short-tailed shrews (Blarina brevicauda) and white-footed mice (Peromyscus leucopus) has been shown previously to be ultrastructurally and serologically distinct from other spirochetes. Two of the original isolates from Connecticut and Minnesota and 16 new isolates obtained from shrews captured in Minnesota were characterized phenotypically and genetically in this study. A comparative analysis of the 16S rRNA sequences of two shrew isolates and one mouse isolate and the 16S rRNA sequences of 16 other spirochetes and Escherichia coli revealed that these organisms exhibited low levels of similarity (range of similarity values, $\mathbf{7 3 . 9}$ to $\mathbf{7 7 . 8 \%}$; average level of similarity, $74.7 \%$ ). The shrew and mouse isolates which we examined formed a deeply branching subgroup that was clearly distinct from the other genera of spirochetes examined. These and other results indicated that the new spirochetes represent a unique taxon in the order Spirochaetales. Accordingly, we propose that they should be classified as members of a new genus, Brevinema. The three strains of Brevinema which we examined had 16S rRNA sequences that were nearly identical. We also compared these isolates by using sodium dodecyl sulfate-polyacrylamide gel electrophoresis, fatty acid and enzyme analyses, restriction endonuclease analysis, and Southern hybridization and found that the levels of genetic and phenotypic homogeneity among the strains were very high. We concluded that the isolates which we examined were members of a single species, for which we propose the name Brevinema andersonii. The type strain of Brevinema andersonii is CT11616 (= ATCC 43811). The guanine-plus-cytosine content of the DNA of this species was determined to be 34 to $36 \mathrm{~mol} \%$ by the thermal denaturation method.
\end{abstract}

In 1987 Anderson et al. described the isolation of morphologically unique spirochetes from the blood and other tissues of the short-tailed shrew (Blarina brevicauda) and the whitefooted mouse (Peromyscus leucopus) in Connecticut and Minnesota (1). Each cell of these spirochetes had single sheathed flagella that extended subterminally from its ends and overlapped near the center. The cells were shorter in length (4 to $5 \mu \mathrm{m})$ and longer in wavelength $(1.5$ to $2.5 \mu \mathrm{m})$ than the cells of most spirochetes. Rabbit and murine antisera to representative Leptospira, Borrelia, Treponema, and Spirochaeta species were not reactive with these spirochetes $(1,5)$. In addition, antisera to four of the shrew-mouse spirochete strains were not reactive with antigens from species belonging to these other spirochete genera. The distinct ultrastructural and serological properties of the spirochetes isolated from shrews and mice suggested that they represent a unique taxon. Partial sequences of the 16S rRNA of a single isolate showed that this spirochete branched separately from other genera (17).

In this paper we describe additional studies performed to classify the spirochetes isolated from shrews and mice. The results of 16S rRNA sequence analysis, DNA restriction enzyme analysis, DNA hybridization analysis, sodium dodecyl sulfate-polyacrylamide gel electrophoresis (SDS-PAGE) analysis, DNA base composition analysis, and enzyme and fatty acid analyses, as well as previously published data, support the conclusion that a single species in a new genus should be created for these organisms. We propose the genus name

\footnotetext{
* Corresponding author. Mailing address: Department of Microbiology, University of Minnesota, 420 Delaware St. S.E., Box 196 UMHC, Minneapolis, MN 55455. Phone: (612) 624-5684. Fax: (612) 626-0623. Internet address: leland@lenti.med.umn.edu.
}

Brevinema for the single species that has been identified so far, Brevinema andersonii.

\section{MATERIALS AND METHODS}

Bacterial strains and culture conditions. The strains of Brevinema andersonii which we used are shown in Table 1 . The spirochetes were cultured in a modified BSK medium (2) which is referred to below as shrew-mouse spirochete medium. Shrew-mouse spirochete medium was prepared as follows. To $900 \mathrm{ml}$ of distilled water we added $3 \mathrm{~g}$ of $\mathrm{N}$-2-hydroxyethylpiperazine- $\mathrm{N}$-2-ethanesulfonic acid (HEPES) (Sigma Chemical Co., St. Louis, Mo.), $5 \mathrm{~g}$ of dextrose, $3 \mathrm{~g}$ of neopeptone (Difco Laboratories, Detroit, Mich.), $1 \mathrm{~g}$ of tryptone (Difco), $3 \mathrm{~g}$ of TC yeastolate (Difco), $0.8 \mathrm{~g}$ of sodium citrate, $2.2 \mathrm{~g}$ of sodium bicarbonate, 0.2 $\mathrm{g}$ of catalase (Sigma), and $0.4 \mathrm{~g}$ of cysteine (Sigma). After these components were fully dissolved, $100 \mathrm{ml}$ of $10 \times 1066 \mathrm{CMRL}$ tissue culture medium (Gibco, Grand Island, N.Y.) was added, and the $\mathrm{pH}$ was adjusted to 7.6. The medium was then filter sterilized, and $35 \mathrm{ml}$ of sterile fetal calf serum (Gibco) and $35 \mathrm{ml}$ of bovine embryonic fluid (Sigma) were added. Finally, $200 \mathrm{ml}$ of sterile $7.5 \%$ gelatin (Difco) was added before dispensing. The final $\mathrm{pH}$ was 7.4 . This medium was dispensed into $7-\mathrm{ml}$ tubes; each tube was filled to $95 \%$ of its capacity and tightly capped to provide a microaerophilic environment. Cultures were incubated at $30^{\circ} \mathrm{C}$. The numbers of cells were determined by using a Petroff-Hausser counting chamber.

Electron microscopy. For transmission microscopy, spirochetes were harvested by centrifugation at $10,000 \times g$, washed twice in phosphate-buffered saline (PBS) $(\mathrm{pH} 7.4)$ at $4^{\circ} \mathrm{C}$, and resuspended in a small volume of PBS. Specimens were placed on Formvar-coated grids and stained for 1 min with $1 \%$ phosphotungstic acid ( $\mathrm{pH} 7.4)$. Specimens for scanning microscopy were prepared by pretreating 10 -mm glass coverslips with $1 \%$ bovine serum albumin and coating the preparations with cells for $20 \mathrm{~min}$ at $37^{\circ} \mathrm{C}$. The cell preparations on coverslips were then immersed in $0.2 \%$ glutaraldehyde, washed in Hanks balanced salt solution, immersed in $1 \%$ glutaraldehyde, washed, and finally treated with $1 \%$ osmium tetroxide; in each fixation step the preparation was incubated at $4^{\circ} \mathrm{C}$ for $1 \mathrm{~h}$. The cells were then dehydrated by using 15 -min incubations in serially increasing concentrations of ethanol from $70 \%$ to absolute. The specimens were removed from ethanol and immediately subjected to critical point drying. Samples were then sputter coated and examined by conventional methods.

Gas chromatographic analysis of cellular fatty acids. Cells were harvested at the mid-exponential growth phase by centrifugation at $10,000 \times g$ and were washed once in PBS ( $\mathrm{pH}$ 7.4). Fatty acids were extracted, separated, and analyzed as described previously (19) by workers at Microbial ID, Newark, Del. 
TABLE 1. Brevinema andersonii strains used

\begin{tabular}{llll}
\hline \multicolumn{1}{c}{ Strain } & \multicolumn{1}{c}{ Source } & \multicolumn{1}{c}{ Location } & Reference(s) \\
\hline CT11616 & Blarina brevicauda & West Haven, Conn. & 1,5 \\
FS47 & Peromyscus leucopus & Minneapolis, Minn. & 1,5 \\
(= MN47) & & & \\
MV104 & Blarina brevicauda & Minneapolis, Minn. & 5 \\
MV116 & Blarina brevicauda & Minneapolis, Minn. & 5 \\
715 & Blarina brevicauda & Columbus, Minn. & 5 \\
7281 & Blarina brevicauda & Lakeville, Minn. & 5 \\
7282 & Blarina brevicauda & Lakeville, Minn. & 5 \\
812 & Blarina brevicauda & Minnetonka, Minn. & 5 \\
8132 & Blarina brevicauda & Columbus, Minn. & 5 \\
8261 & Blarina brevicauda & Andover, Minn. & 5 \\
8274 & Blarina brevicauda & Linwood, Minn. & 5 \\
901 & Blarina brevicauda & Columbus, Minn. & 5 \\
9031 & Blarina brevicauda & Chaska, Minn. & 5 \\
9033 & Blarina brevicauda & Columbus, Minn. & 5 \\
9035 & Blarina brevicauda & Hollywood, Minn. & 5 \\
9102 & Blarina brevicauda & Champlin, Minn. & 5 \\
9292 & Blarina brevicauda & Forest Lake, Minn. & 5 \\
1071 & Blarina brevicauda & Chaska, Minn. & 5 \\
\hline
\end{tabular}

SDS-PAGE. Proteins were separated by using the SDS-PAGE procedure described by Guilian et al. (7). Cells in the early- to mid-log stage of growth were harvested by centrifugation at $10,000 \times g$ for $20 \mathrm{~min}$, washed twice in PBS (pH 7.4), and resuspended in buffer. The protein concentration in the cells was determined by using a modified Bradford assay (Bio-Rad, Mellville, N.Y.) Samples were boiled in buffer containing $2 \%$ (vol/vol) SDS and $15 \mathrm{mM}$ dithiothreitol, and 2 to $5 \mu \mathrm{g}$ of protein per lane was subjected to electrophoresis on a $12 \%$ polyacrylamide gel. Protein was then visualized by silver staining as described previously (7).

Western blot (immunoblot) analysis. Proteins were transferred from SDSPAGE gels to polyvinylidene difluoride membranes (Immobilon P; Millipore, Bedford, Mass.) by using the buffer system of Towbin et al. (20) and a Transphor cell (Hoefer Scientific Instruments, San Francisco, Calif.) at $1.0 \mathrm{~A}$ for $30 \mathrm{~min}$. Membranes were processed as previously described (3) by using a 1:5,000 dilution of immune rabbit sera.

Isolation of DNA. DNA was isolated and purified by using the method described by Lefebvre et al. (13). Cultures $(50 \mathrm{ml})$ of exponentially growing cells were harvested by centrifugation at $10,000 \times g$ and then washed once in PBS (pH 7.4). DNA was extracted and purified exactly as described previously (13).

Restriction endonuclease analysis. DNA was digested with $1 \mathrm{U}$ of restriction endonuclease per $\mu \mathrm{g}$ of DNA in the appropriate buffers (Boehringer Mannheim Corp., Indianapolis, Ind.) for $5 \mathrm{~h}$ at $37^{\circ} \mathrm{C}$. Fragments were separated in $1.2 \%$ agarose by electrophoresis, using Tris-acetate buffer $(\mathrm{pH} 7.2)$. Lambda phage DNA digested with HindIII was used as a molecular weight standard. DNA was also separated by clamped homogeneous electric field electrophoresis, using a model LKB 2015 Pulsaphor system (Pharmacia LKB Biotechnology, Uppsala, Sweden). Cells and DNA were prepared as previously described (8). Field geometry varied, and the conditions necessary for optimal separation of DNA were determined.

Southern hybridization. DNA was isolated, purified, and separated as described above. After electrophoresis and depurination, DNA was transferred to membranes (GeneScreen; NEN Research, Boston, Mass.). Genomic probe DNA was digested with EcoRI and labeled for detection by chemiluminescence (Boehringer Mannheim). DNA labeling with digoxigenin and hybridization were carried out according to the instructions of the manufacturer. Hybridization was performed at $60^{\circ} \mathrm{C}$ by using $500 \mathrm{ng}$ of labeled DNA. Following hybridization, the membranes were washed twice in $2 \times \mathrm{SSC}(1 \times \mathrm{SSC}$ is $0.15 \mathrm{M} \mathrm{NaCl}$ plus $0.015 \mathrm{M}$ sodium citrate) containing $0.1 \%$ SDS at room temperature, twice for $30 \mathrm{~min}$ in $0.5 \times \mathrm{SSC}-0.1 \% \mathrm{SDS}$ at $65^{\circ} \mathrm{C}$, and once in $0.1 \times \mathrm{SSC}$ for $15 \mathrm{~min}$ at $65^{\circ} \mathrm{C}$. Hybridized probe DNA was detected by using the procedure recommended by the manufacturer.

DNA base composition. The base composition of spirochetal DNA was determined by the method of Marmur and Doty (14). The thermal denaturation

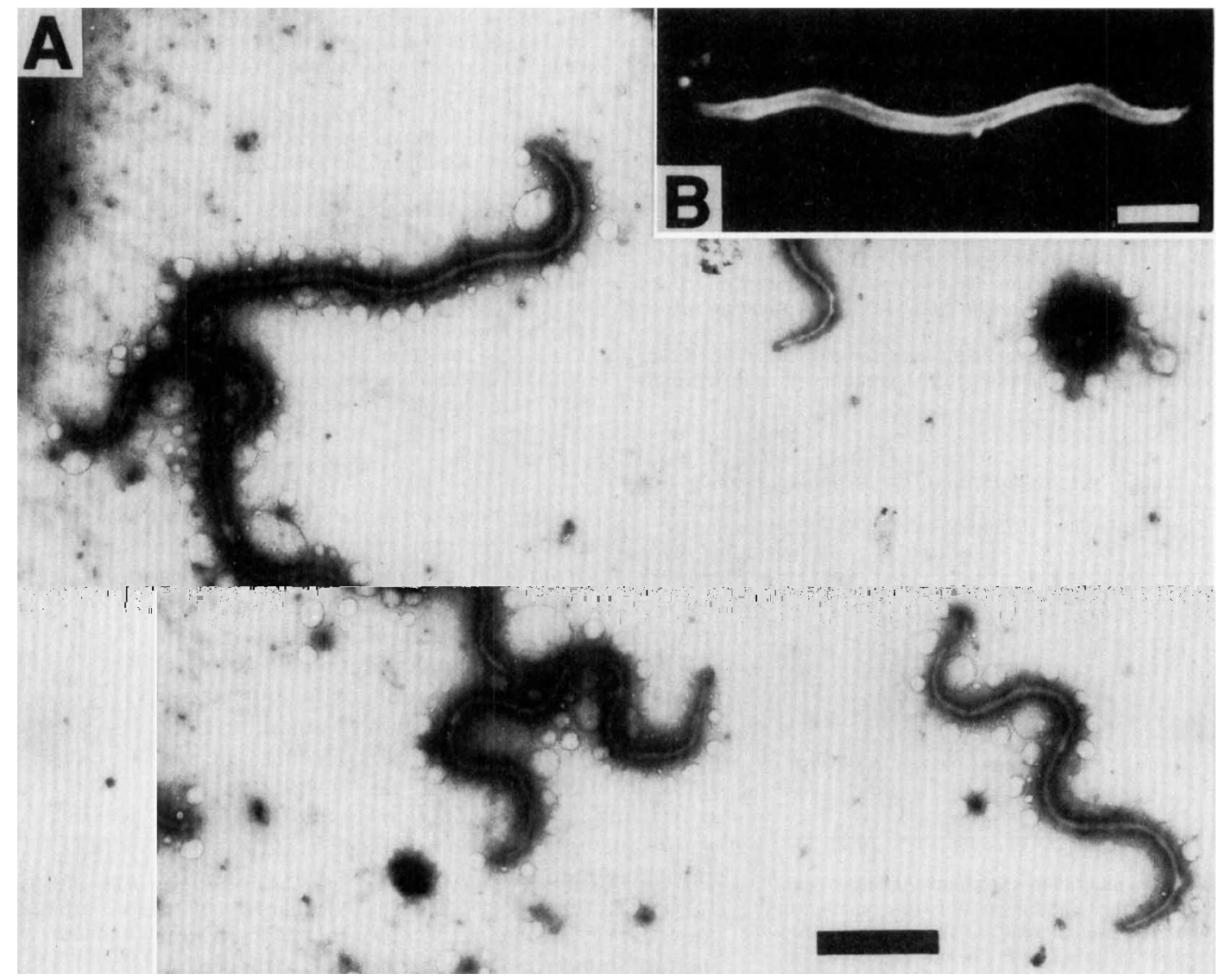

FIG. 1. Brevinema andersonii $\mathrm{CT} 11616^{\mathrm{T}}$. (A) Transmission electron micrograph of negatively stained preparation. $(\mathrm{B})$ Scanning electron micrograph. Bars $=1.0$ um. 


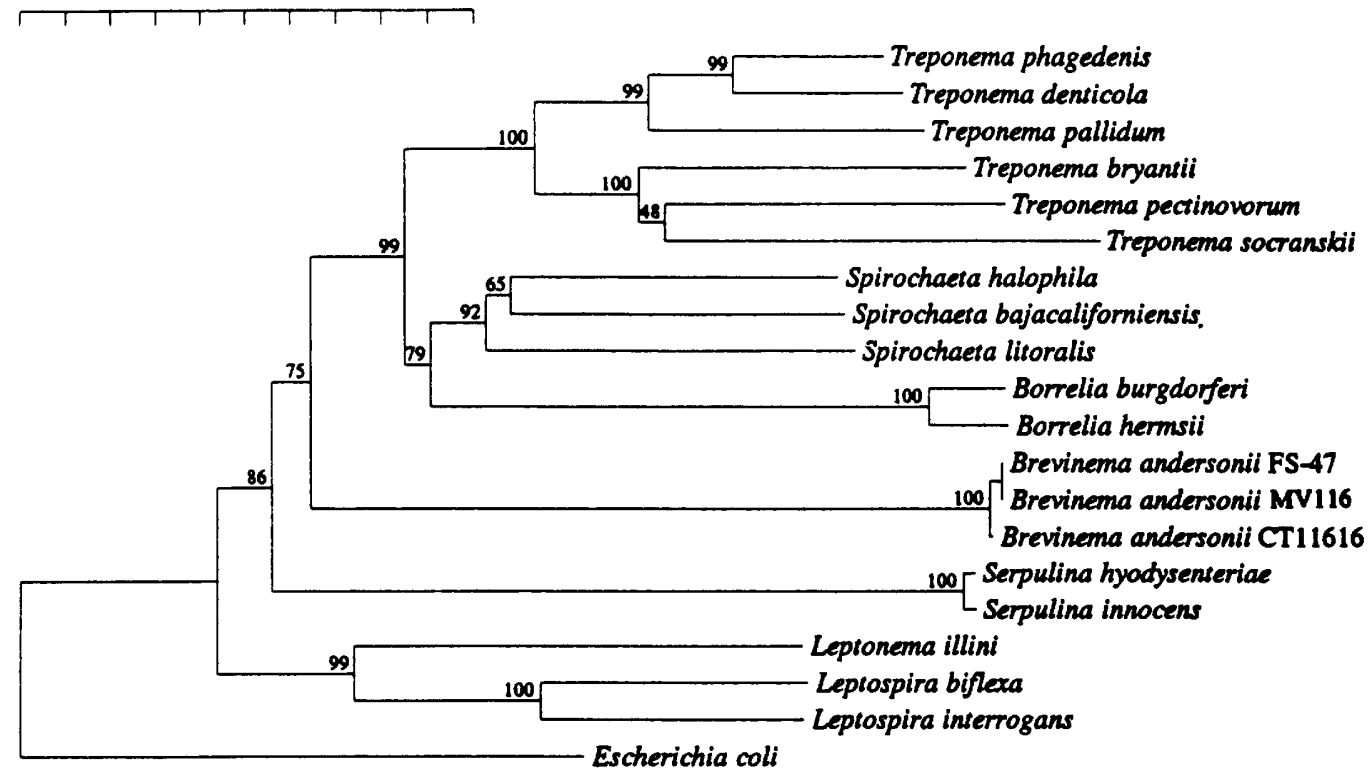

FIG. 2. Dendrogram showing the phylogenetic relationship between Brevinema andersonii and other spirochetes, with E. coli as the outgroup. Horizontal distance is proportional to the difference between sequences, expressed as a percentage. Bar $=10 \%$ difference in nucleotide sequences. Values at branch points represent bootstrap confidence intervals.

kinetics of DNA samples were determined by using a Gilford Response spectrophotometer and thermal programming software (Ciba Corning Diagnostics Corp., Medford, Mass.). Samples $(10 \mu \mathrm{g})$ of DNA were suspended in $200 \mu \mathrm{l}$ of $1 \times$ SSC in a thermocuvette, and the temperature was increased at a rate of $0.1^{\circ} \mathrm{C} / \mathrm{min}$. The melting temperature $\left(T_{m}\right)$ was determined from the midpoint of the increase in absorbance. The guanine-plus-cytosine $(\mathrm{G}+\mathrm{C})$ content was calculated by using the following equation: $\mathrm{G}+\mathrm{C}$ content $=\left(T_{m}-69.3\right) \times 2.44$ (14). The values given below are the means of the values from at least three separate experiments in which the standard deviations were less than $10 \%$ of the means. DNA samples from Borrelia burgdorferi, Leptospira interrogans, and Treponema phagedenis were analyzed simultaneously as controls.

16S rRNA isolation and sequencing. rRNA was isolated and partially purified by the method described by Pace et al. (15), as modified by these authors (15). Reverse transcriptase was used to elongate eight primers complementary to conserved eubacterial $16 \mathrm{~S}$ rRNA regions. Sequences were determined directly by a modified Sanger dideoxy chain termination method (11). The primers which we used have been described elsewhere (6).

Sequences were aligned, similarity matrices were constructed, and tree configurations were determined by using a computer algorithm written in Microsoft

TABLE 2. Single-base signatures of Brevinema andersonii

\begin{tabular}{lccc}
\hline $\begin{array}{l}\text { Position(s) } \\
\text { of base(s) }\end{array}$ & $\begin{array}{c}\text { Composition in } \\
\text { eubacteria }^{b}\end{array}$ & $\begin{array}{c}\text { Composition in } \\
\text { spirochetes }^{c}\end{array}$ & $\begin{array}{c}\text { Composition in } \\
\text { Brevinema andersonii }^{a}\end{array}$ \\
\hline $28 \cdot 555$ & $\mathrm{G} \cdot \mathrm{C}$ & $\mathrm{A} \cdot \mathrm{U}$ & $\mathrm{A} \cdot \mathrm{U}$ \\
47 & $\mathrm{C}$ & $\mathrm{U}$ & $\mathrm{U}$ \\
50 & $\mathrm{~A}$ & $\mathrm{U}$ & $\mathrm{U}$ \\
$52 \cdot 359$ & $\mathrm{C} \cdot \mathrm{G}$ or $\mathrm{U} \cdot \mathrm{A}$ & $\mathrm{A} \cdot \mathrm{U}$ & $\mathrm{G} \cdot \mathrm{C}$ \\
$53 \cdot 358$ & $\mathrm{~A} \cdot \mathrm{U}$ & $\mathrm{G} \cdot \mathrm{C}$ & $\mathrm{G} \cdot \mathrm{C}$ \\
$783 \cdot 799$ & $\mathrm{G} \cdot \mathrm{C}$ & $\mathrm{G} \cdot \mathrm{C}$ & $\mathrm{A} \cdot \mathrm{U}$ \\
361 & $\mathrm{G}$ & $\mathrm{A}$ & $\mathrm{A}$ \\
893 & $\mathrm{C}$ & $\mathrm{U}$ & $\mathrm{C}$ \\
$1415 \cdot 1485$ & $\mathrm{G} \cdot \mathrm{Y}$ & $\mathrm{C} \cdot \mathrm{G}$ & $\mathrm{C} \cdot \mathrm{G}$ \\
\hline
\end{tabular}

${ }^{a}$ Position(s) in E. coli rRNA (4).

${ }^{b}$ Composition in 250 to 350 eubacteria other than spirochetes. Different bases occur in the sequences of a few strains at the following positions (the numbers in parentheses are the numbers of taxa that have different bases): positions $28 \cdot 555$ (2), $47(2), 50(4), 52 \cdot 359(1), 53 \cdot 358(3), 361(2), 893(3)$, and $1415 \cdot 1485$ (4). ${ }^{c}$ Composition in the spirochetes shown in Table 3 . The only exception is at positions $53 \cdot 358$; at these positions the composition is $\mathrm{U} \cdot \mathrm{A}$ in Leptospira spp. and Leptonema illini.
Quick Basic (17). The sequences were aligned as previously described (16). Only unambiguously aligned sequences were used in the comparisons which served as the basis for calculations of levels of similarity. Similarity matrices were corrected for multiple base changes at single locations by the method of Jukes and Cantor (9). The neighbor-joining method of Saitou and Nei was used to construct dendrograms (18). The reliability of tree nodes was analyzed by using the bootstrapping program MEGA (10). A total of 300 bootstrap trees were generated, and the bootstrap confidence levels were determined.

Nucleotide accession numbers. Nucleotide sequence data are available from the EMBL, GenBank, and DDBJ nucleotide sequence databases under the following accession numbers: Brevinema andersonii CT11616 ${ }^{\mathrm{T}}(\mathrm{T}=$ type strain), M59179; Brevinema andersonii FS47, L31543; Brevinema andersonii MV116, L31544; Treponema pallidum Nichols, M34266; Treponema bryantii RUS-1 ${ }^{\mathrm{T}}$, M57737; Treponema denticola ATCC 33520, M71236; Treponema succinifaciens $6091^{\mathrm{T}}$, M57738; Spirochaeta aurantia $\mathrm{J}^{\mathrm{T}}{ }^{\mathrm{T}}$, M57740; Spirochaeta halophilia $\mathrm{RS} 1^{\mathrm{T}}$, M34262; Spirochaeta litoralis R1 ${ }^{\mathrm{T}}$, M34263; Borrelia burgdorferi $\mathrm{B} 31^{\mathrm{T}}$, M59293; Borrelia hermsii M1001, M72398; Leptonema illini 3055, M34118; Leptospira sp. strain A183, M34261; Leptospira interrogans serovar canicola strain Moulton, X17547; Serpulina hyodysenteriae B78 ${ }^{\mathrm{T}}$, M57741; and Serpulina innocens B256 $^{\mathrm{T}}$, M57744. Escherichia coli sequences have been published previously (4).

\section{RESULTS AND DISCUSSION}

Brevinema andersonii grew optimally in shrew-mouse spirochete medium. This culture medium differed considerably from BSK medium as it did not contain $N$-acetylglucosamine or pyruvate. Bovine serum albumin was not required for growth of Brevinema andersonii. In addition, tryptone, catalase, and cysteine were added, and fetal calf serum was substituted for rabbit serum. Serum, reducing agents, and peptones were required for growth. Growth in this medium occurred when we used a small inoculum (10 cells per $\mathrm{ml}$ ). The spirochetes grew optimally at 30 to $34^{\circ} \mathrm{C}$ and $\mathrm{pH} 7.4$ with a generation time of 11 to $14 \mathrm{~h}$ and a typical final density of $4 \times 10^{8}$ cells per ml. Cells of Brevinema andersonii CT11616 ${ }^{\mathrm{T}}$ grown in shrew-mouse spirochete medium were 0.2 to 0.3 by 4 to $5 \mu \mathrm{m}$ (Fig. 1).

We determined approximately $95 \%$ of the 16 S rRNA sequences of Brevinema andersonii MV116 and FS47. The aligned sequences were compared with the previously published sequences of strain CT11616 ${ }^{\mathrm{T}}, 16$ other spirochetes that are representatives of known spirochete genera, and $E$. coli 
TABLE 3. Similarity matrix

\begin{tabular}{|c|c|c|c|c|c|c|c|c|c|c|c|c|c|c|c|c|c|c|c|c|}
\hline \multirow[b]{2}{*}{ Bacterial species } & \multirow[b]{2}{*}{ B.a1 } & \multirow[b]{2}{*}{ B.a2 } & \multirow[b]{2}{*}{ B.a3 } & \multirow[b]{2}{*}{ B.b } & \multirow[b]{2}{*}{$B . h$} & \multirow[b]{2}{*}{ S.h } & \multirow[b]{2}{*}{ s.t } & \multicolumn{6}{|c|}{$\%$ similarity and $\%$ difference with: } & \multirow[b]{2}{*}{$T . s$} & \multirow[b]{2}{*}{ S.h } & \multirow[b]{2}{*}{ S.i } & \multirow[b]{2}{*}{$L . i$} & \multirow[b]{2}{*}{ L.b } & \multirow[b]{2}{*}{ L.in } & \multirow[b]{2}{*}{ E.c } \\
\hline & & & & & & & & S.b & T.pa & T.ph & T.d & T.b & T.pe & & & & & & & \\
\hline Brevinema andersonii FS-47 & & 100.0 & 99.7 & 75.3 & 75.0 & 77.5 & 77.0 & 77.8 & 76.2 & 76.7 & 75.7 & 74.3 & 75.5 & 74.5 & 74.3 & 74.2 & 75.1 & 75.6 & 75.5 & 73.3 \\
\hline Brevinema andersonii MV116 & 0.0 & & 99.7 & 75.3 & 75.0 & 77.5 & 77.0 & 77.8 & 76.2 & 76.7 & 75.7 & $\mathbf{7 4 . 3}$ & 75.5 & $\mathbf{7 4 . 5}$ & $\mathbf{7 4 . 3}$ & 74.2 & 5.1 & 75.6 & 75.5 & 73.3 \\
\hline revinema andersonii CT11616 & 0.3 & 0.3 & & 75.5 & 75.4 & 78.1 & 77.5 & 77.8 & 76.4 & 76.9 & 76.0 & 74.5 & 75.5 & 74.4 & 73.9 & 74.1 & 4.9 & 75.7 & 75.5 & 73.7 \\
\hline orrelia burgdorf & 29.9 & 29.9 & 29.6 & & 96.6 & 80.9 & 81.4 & 80.6 & 79.2 & 78.4 & 79.3 & 78.6 & 78.2 & 75.7 & 75.0 & 74.6 & 74.6 & 77.2 & 76.2 & 72.3 \\
\hline orrelia $h$ & 30.3 & 30.3 & 29.9 & 3.4 & & 81.3 & 81.3 & 81.8 & 79.4 & 77.9 & 78.5 & 79.0 & 78.6 & 75.9 & 74.6 & 74.3 & 4.5 & 76.2 & 75.7 & 72.3 \\
\hline Ieta haloph & 26.7 & 26.7 & 26.0 & 22.1 & 21.5 & & 85.9 & 86.9 & 81.7 & 82.4 & 82.1 & 81.6 & 79.9 & 79.3 & 77.8 & 77.8 & 76.9 & 77.6 & 77.8 & 74.4 \\
\hline pir & 27.5 & 27.5 & 26.8 & 21.4 & 21.5 & 15.6 & & 85.6 & 81.9 & 82.3 & 81.5 & 80.8 & 81.3 & 77.5 & 75.3 & 75.4 & 77.3 & 77.7 & 77.1 & 74.3 \\
\hline pirc & 26.3 & 26.3 & 26.3 & 22.4 & 20.8 & 14.4 & 16.0 & & 83.0 & 82.1 & 82.1 & 81.1 & 79.2 & 79.6 & 76.0 & 76.6 & & 78.8 & 78.9 & 75.2 \\
\hline Trepone & 28.7 & 28.7 & 28.3 & 24.4 & 24.1 & 21.0 & 20.7 & 19.2 & & 90.1 & 88.7 & 82.5 & 83.3 & 81.9 & 76.1 & 76.3 & 76.3 & 75.8 & 76.5 & 74.3 \\
\hline & & 27.9 & 27.6 & 25.5 & 26.2 & 20.1 & 20.2 & 20.4 & 10.6 & & 93.2 & 84.2 & 5.5 & & 76.8 & & 76.4 & 75.7 & 76.0 & 75.4 \\
\hline Trepo & .3 & 29.3 & 28.9 & 24.3 & 25.3 & 20.5 & 21.2 & 20.4 & 12.3 & 7.1 & & 84.9 & 85.4 & 83.7 & 76.5 & 76.5 & 75.9 & 76.0 & 75.6 & 74.3 \\
\hline & & 31.5 & 31.2 & 25.2 & 24.7 & 21.2 & 22.2 & 21.8 & 20.0 & 17.7 & 16.8 & & 86.9 & 83.8 & 76.1 & 76.2 & 76.6 & 74.9 & 75.2 & 73.7 \\
\hline Trepo & & 29.6 & 29.7 & 25.7 & 25.1 & 23.4 & 21.5 & 24.4 & 18.9 & 16.1 & 16.2 & 14.3 & & & 74.2 & 74 & 75.2 & 74.5 & 73.8 & 72.2 \\
\hline Treponem & .1 & 31.1 & 31.4 & 29.4 & 29.1 & 24.2 & 26.8 & 23.8 & 20.7 & 18.4 & 18.3 & 18.3 & 17.1 & & 73.4 & 73.4 & 74.1 & 74.0 & 74.2 & 71.2 \\
\hline Serpulina & & & 32.1 & & & 26.4 & 29.9 & & 28.8 & 27.8 & 28.2 & 28.8 & 31.6 & & & 99.5 & 75.6 & 75.5 & 75.1 & 73.5 \\
\hline Serpuli & & 31.6 & 31.7 & 31.1 & 31.5 & 26.3 & 29.9 & 28.1 & 28.5 & 27.6 & 28.2 & 28.7 & 31.5 & 32.9 & 0.5 & & 75.6 & 75.3 & 74.9 & 73.2 \\
\hline & & 30.3 & 30.6 & 31.0 & 31.1 & 27.6 & 27.1 & 25.2 & 28.5 & 28.3 & 29.0 & 28.0 & 30.1 & 31 & 29.6 & & & 82.0 & 83.6 & 75.8 \\
\hline Leptos & & 29.5 & 29.4 & & 28.6 & 26.6 & & & 29.3 & 29.4 & 28.9 & 30.5 & & & 29.7 & 29.9 & 20.6 & & 89.3 & 75.1 \\
\hline & & 29.7 & 29.7 & 28. & 29.3 & 26.4 & 27. & 24. & 28.2 & 28.9 & 29.4 & 30.1 & 32.3 & 31 & 30.3 & 30.5 & 18.5 & 11.6 & & 75.7 \\
\hline Escherichia coll & 33.0 & 33.0 & 32.4 & 34.6 & 34.6 & 31.3 & 31.4 & 30.0 & 31.5 & 29.8 & 31.5 & 32.4 & 34.7 & 36.3 & 32.7 & 33.1 & 29.3 & 30.2 & 29.4 & \\
\hline
\end{tabular}

${ }^{a}$ The values on the upper right are uncorrected percentages of similarity, and the values on the lower left are percentages of difference corrected for multiple base changes. Abbreviations: B.a1, Brevinema andersonii FS47; B.a2, Brevinema andersonii MV116; B.a3, Brevinema andersonii CT11616 ${ }^{\mathrm{T}}$; B.b, Borrelia burgdorferi; B.h, Borrelia hermsii; S.h, Spirochaeta halophila; S.l, Spirochaeta litoralis; S.b, Spirochaeta bajacaliforniensis; T.pa, Treponema pallidum; T.ph, Treponema phagedensis; T.d, Treponema denticola; T.b, Treponema bryantii; T.pe, Treponema pectinovorum; T.s, Treponema socranskii; S.h, Serpulina hyodysenteriae; S.i, Serpulina innocens; L.i, Leptonema illini; L.b, Leptospira biflexa; L.in, Leptospira interrogans; E.c, Escherichia coli.

(17). A comparative analysis of the sequences revealed similarities between other genera of spirochetes, and the sequence data were consistent with classification of the genus Brevinema as a separate genus $(17,22)$. The topology of the dendrogram created from 16S rRNA sequences (Fig. 2) revealed that the genus Brevinema is a separate and deeply branching subgroup of the order Spirochaetales. Designation of a separate genus for
Brevinema strains was also supported by the results of the bootstrap analysis as the confidence level for each of the spirochete subgroups was $100 \%$.

The results of a single-base signature analysis revealed that the genus Brevinema is related to other spirochetes and provided evidence that this genus should be included in the order Spirochaetales (Table 2) (17). The unique base compo-

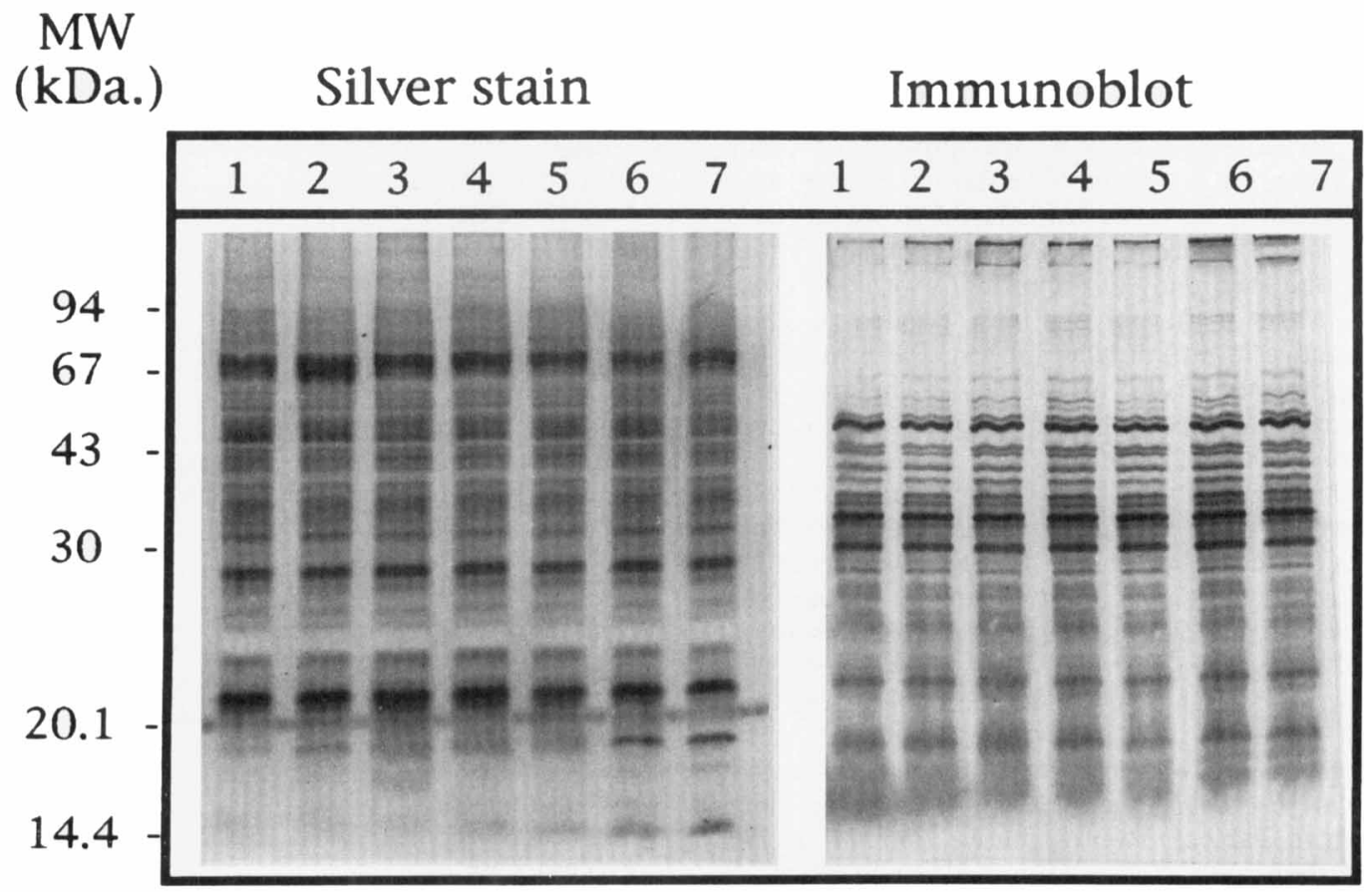

FIG. 3. Silver-stained electrophoretic profiles of various Brevinema andersonii strains and Western blots of identical samples probed with rabbit antisera against strain CT11616 ${ }^{\mathrm{T}}$. Lanes 1 through 7, strains CT11616 ${ }^{\mathrm{T}}$, FS47, MV104, MV116, 715, 7281, and 7282, respectively. Molecular masses (in kilodaltons) are indicated on the left. MW, molecular weight. 
TABLE 4. Fatty acid compositions of Brevinema andersonii strains

\begin{tabular}{|c|c|c|c|c|c|c|c|c|c|c|c|c|c|c|c|c|c|}
\hline \multirow[b]{2}{*}{ Strain } & \multicolumn{17}{|c|}{ Relative peak area $(\%)$} \\
\hline & $12: 0^{a}$ & 13:0 & $14: 0$ & $14: 0 \mathrm{~A}^{b}$ & $15: 0$ & $16: 0$ & $\begin{array}{l}16: 0 \\
3 \mathrm{OH}\end{array}$ & $16: 1$ & 18:0 & $18: 1$ & $18: 2$ & $18: 3$ & 19:0 & 19:1 & 19:2 & $20: 3$ & $20: 4$ \\
\hline CT11616 ${ }^{\mathrm{T}}\left(=\right.$ ATCC $\left.43811^{\mathrm{T}}\right)$ & 0.4 & 0.4 & 47.5 & 0.5 & 2.0 & 20.7 & $\mathrm{ND}^{c}$ & ND & 5.3 & 8.2 & 5.6 & 1.4 & 0.6 & ND & ND & 3.2 & 2.5 \\
\hline PS47 (= ATCC 43810$)$ & 0.5 & 0.3 & 46.6 & 0.4 & 1.7 & 21.8 & 0.4 & ND & 5.3 & 10.2 & 6.1 & 1.1 & ND & ND & ND & 3.2 & 2.5 \\
\hline MV104 & 0.5 & 0.4 & 42.6 & 0.4 & 1.8 & 22.2 & 0.5 & 0.5 & 5.4 & 13.1 & 5.7 & 1.1 & ND & ND & ND & 3.5 & 2.5 \\
\hline MV116 & 0.5 & ND & 40.3 & ND & 1.9 & 20.8 & ND & ND & 7.4 & 9.3 & 5.8 & 1.2 & 4.4 & 0.9 & 1.7 & 3.3 & 2.5 \\
\hline
\end{tabular}

${ }^{a}$ The number before the colon is the number of carbon atoms in the chain, and the number after the colon is the number of double bonds.

${ }^{b}$ Aldehyde.

${ }^{c} \mathrm{ND}$, not detected.

sition of members of the genus Brevinema at positions $52 \cdot 359$ and $783 \cdot 799$ further distinguishes this genus as a separate and distinct subgroup of spirochetes. Furthermore, the sequences of Brevinema andersonii did not possess the usual 20- to 30-base extension at the $5^{\prime}$ end which is typical of Treponema, Spriochaeta, Leptospira, and Leptonema sequences. We identified a 27-nucleotide signature sequence (5'-GGCAGCUAC CUAUGCUAAGAUUGACGC- $3^{\prime}$, equivalent to positions 724 to 750 in $E$. coli [4]) that differed from the signature sequences of other spirochetes in 6 to 12 bases. This sequence, which was found in the three strains examined, could potentially serve as a target region for Brevinema strains and may be useful for creating species- or genus-specific DNA probes. Such probes would be useful for rapid screening, detection, and identification of new isolates.

The rRNA sequences of strains FS47, MV116, and CT11616 ${ }^{\mathrm{T}}$, which were isolated from a Minnesota mouse, a Connecticut shrew, and a Minnesota shrew, respectively, were nearly identical (Table 3). The few differences in base composition may have been due to sequencing error or strain variation.

The homogeneity of the 16S rRNA sequences of these three strains was reflected in the phenotypic and genotypic characteristics of the isolates. The results of SDS-PAGE obtained for seven Brevinema strains (Fig. 3) revealed the homogeneity of the phenotypes of the isolates. Approximately 40 to 50 bands were produced on SDS-PAGE gels. The profiles of other isolates were indistinguishable from those shown in Fig. 3 (data not shown). When proteins were transferred to membranes and probed with rabbit hyperimmune sera raised against strain CT11616 ${ }^{\mathrm{T}}$, we found that many of the proteins were immunogenic in rabbits. Most of the polypeptides revealed by silver staining were reactive in an immunoblot test. Patterns of the reactive polypeptides observed in profiles of heterologous isolates were identical to those of the polypeptides that reacted with homologous strain CT11616 ${ }^{\mathrm{T}}$ (Fig. 3).

The fatty acid compositions of four Brevinema andersonii isolates are shown in Table 4 . We found that the major fatty acid components of the cells were myristic acid (14:0), palmitic acid (16:0), and oleic acid (18:1) and that smaller amounts of stearic acid (18:0) and linoleic acid (18:2) were also present; in addition, several fatty acids were detected at low levels (less than $1 \%$ ). We found few significant differences among the four strains analyzed.

The API ZYM system was used to examine constitutive enzyme activity in Brevinema isolates. The results of these assays are shown in Table 5. Representative Borrelia, Treponema, and Leptospira species were examined concurrently as controls, and our results were always consistent with the previously published profiles.

Isolate CT11616 ${ }^{\mathrm{T}}$ from a Connecticut shrew, isolate FS47 from a Minnesota mouse, and isolates 901 and 8274, two Minnesota shrew isolates, had $\mathrm{G}+\mathrm{C}$ contents of $36,35,34$, and $34 \mathrm{~mol} \%$, respectively.

To determine the levels of genetic relatedness of Brevinema andersonii isolates to each other, a restriction enzyme analysis was performed. The results of separation of SfuI-digested Brevinema andersonii genomic DNAs by electrophoresis are

TABLE 5. Enzyme activities of Brevinema andersonii

\begin{tabular}{|c|c|}
\hline Enzyme & $\begin{array}{l}\% \text { of strains with } \\
\text { activity }(n=18)\end{array}$ \\
\hline \multicolumn{2}{|l|}{ Aminopeptidases } \\
\hline 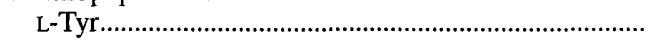 & 0 \\
\hline L-Glu & 0 \\
\hline L-Phe & 0 \\
\hline 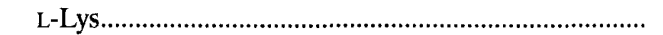 & 0 \\
\hline 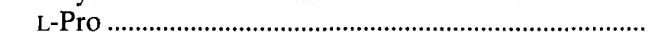 & 0 \\
\hline 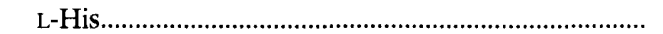 & 0 \\
\hline L-Gly & 0 \\
\hline 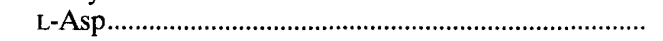 & 0 \\
\hline L-Arg & 0 \\
\hline L-Ala & 0 \\
\hline 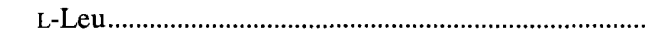 & 0 \\
\hline L-Val & 0 \\
\hline 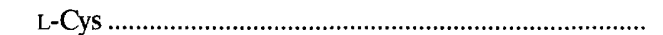 & 0 \\
\hline \multicolumn{2}{|l|}{ Esterases } \\
\hline Butyrate $\left(\mathrm{C}_{4}\right)$ & 100 \\
\hline Valerate $\left(C_{5}\right)$ & 100 \\
\hline Caproate $\left(C_{6}\right)$ & 100 \\
\hline Caprylate $\left(\mathrm{C}_{8}\right)$ & 100 \\
\hline Nonanoate $\left(\mathbf{C}_{9}\right)$ & 100 \\
\hline 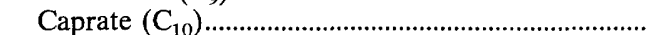 & 83 \\
\hline Laurate $\left(C_{12}\right)$ & 0 \\
\hline Myristate $\left(\mathrm{C}_{14}\right)$ & 0 \\
\hline Palmitate $\left(\mathrm{C}_{16}\right)$ & 0 \\
\hline Stearate $\left(\dot{C}_{18}\right)$ & 0 \\
\hline Esterase lipase $\left(\mathrm{C}_{4}\right)$ & 89 \\
\hline Lipase $\left(\mathrm{C}_{14}\right)$ & 0 \\
\hline \multicolumn{2}{|l|}{ Other enzymes } \\
\hline Alkaline phosphatase & 100 \\
\hline Acid phosphatase & 100 \\
\hline 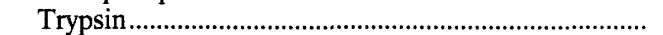 & 0 \\
\hline Chymotrypsin & 0 \\
\hline 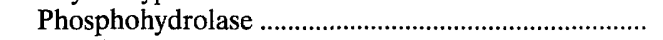 & 0 \\
\hline$\alpha$-Galactosidase & 0 \\
\hline 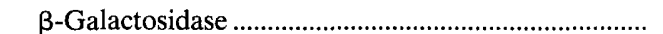 & 0 \\
\hline$\beta$-Glucuronidase & 78 \\
\hline$\alpha$-Glucosidase & 0 \\
\hline$\beta$-Glucosidase & 0 \\
\hline$N$-Acetylglucosaminidase & 0 \\
\hline$\alpha$-Mannosidase & 0 \\
\hline$\alpha$-Fucosidase & 0 \\
\hline
\end{tabular}



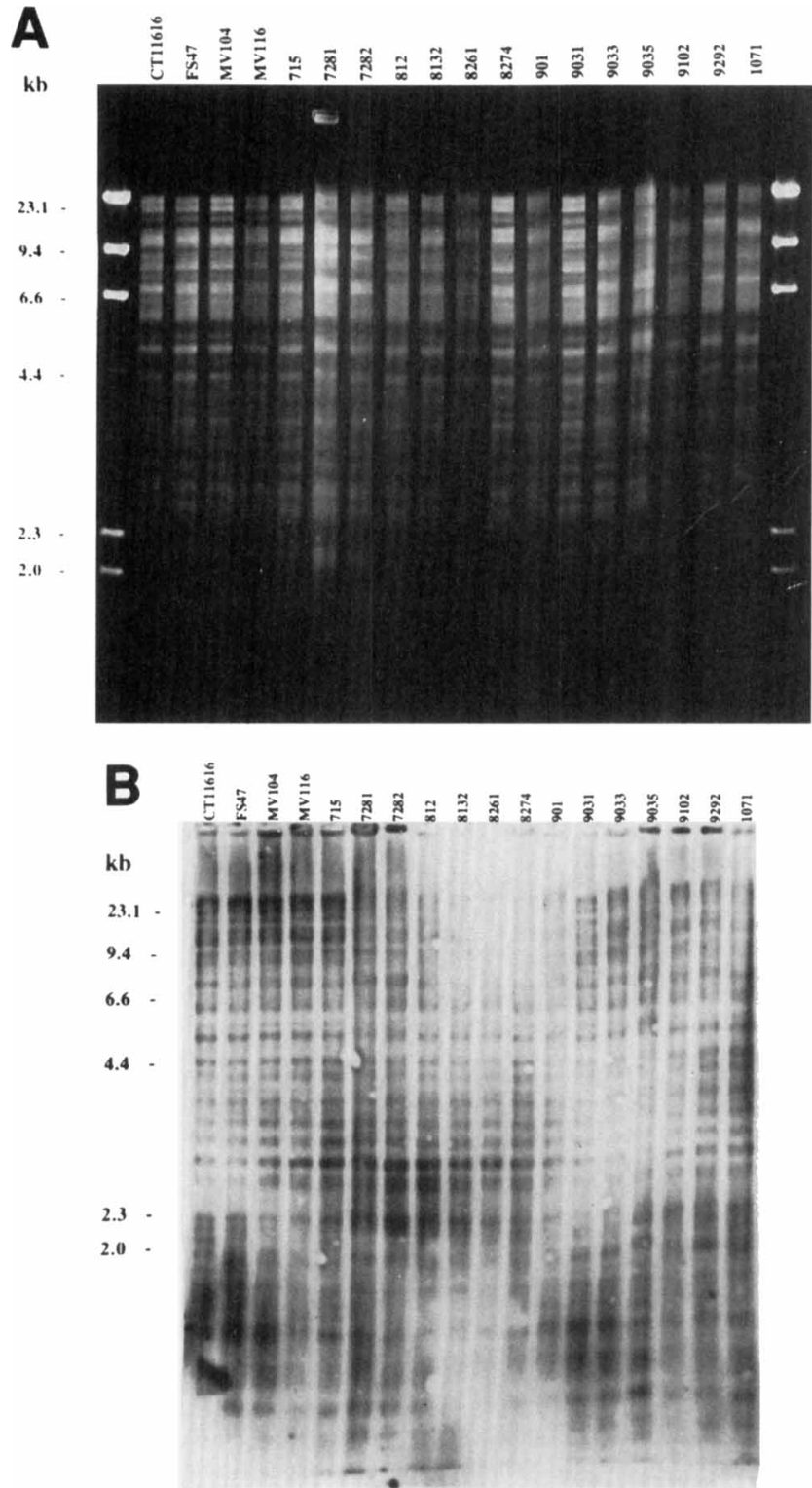

FIG. 4. Restriction enzyme analysis of fragment patterns and Southern hybridization of DNAs from Brevinema andersonii isolates. (A) SfuI-digested genomic DNAs separated by using a $1.2 \%$ agarose gel. (B) DNAs from the SfuI digests were transferred to a membrane and hybridized with labeled genomic DNA from strain CT11616 ${ }^{\mathrm{T}}$. The strain in each lane is indicated at the top. The positions of molecular size markers (in kilobase pairs) are indicated on the left.

shown in Fig. 4A. The patterns of bands obtained for all 18 isolates under these conditions were virtually identical. The same degree of homogeneity was obtained when we used different restriction enzymes and both constant-field electrophoresis and pulsed-field gel electrophoresis (data not shown). To further assess the genetic relatedness of the isolates, SfuI digests were transferred to membranes and probed with labeled CT11616 ${ }^{\mathrm{T}}$ genomic DNA under high-stringency conditions. This probe hybridized strongly to all isolates, and the patterns resulting from DNA-DNA hybridization were essentially identical, demonstrating the close genetic relatedness of the organisms (Fig. 4B).

The results of previous studies of the shrew-mouse spirochete led investigators to suggest that this organism represents a unique taxon belonging to the order Spirochaetales $(1,2,12$, $13,17)$. Our results supported and extended this suggestion by providing data for a number of isolates obtained from different hosts and geographic regions. Our results contributed phenotypic, genetic, and phylogenetic evidence which indicated that the strains which we examined are closely related members of a distinct taxon of spirochetes. The phylogenetic distance of this group of organisms from other spirochete genera indicated that it should be classified as a distinct genus.

On the basis of the results of phenotypic analyses of the 18 Brevinema andersonii isolates which we studied we were not able to distinguish between strains. The enzyme profiles of the Brevinema andersonii strains indicated that they are members of a single biotype. Furthermore, the protein profiles and immunoblot data did not provide distinguishing characteristics or establish the presence of separate serotypes.

Brevinema andersonii can be readily distinguished from other spirochetes on the basis of its unique morphological characteristics (1). In addition, the genus Brevinema can be differentiated from other genera by several types of data. Brevinema strains are serologically distinct from other spirochetes $(1,5)$, and Brevinema andersonii DNA exhibits no detectable hybridization with DNAs from members of other genera, as determined by Southern analysis $(5,12,13)$. In addition, we identified a nucleic acid sequence that corresponds to an rRNA region in Brevinema andersonii that differentiates this organism from other spirochetes. This sequence may be useful for constructing DNA probes for identification of Brevinema andersonii. At the species level, Brevinema andersonii can be readily identified by restriction enzyme analysis, and SDS-PAGE, or fatty acid composition data. As determined by comparative $16 \mathrm{~S}$ rRNA analysis, restriction enzyme analysis, and SDS-PAGE patterns, Brevinema andersonii isolates are members of a genetically homologous group, despite their diverse hosts and diverse geographic origins.

Description of the genus Brevinema Defosse, Johnson, Paster, Dewhirst, and Fraser gen. nov. Brevinema (Brev. i. ne' ma. L. adj. brevis, short; Gr. n. nema, thread; N.L. neut. n. Brevinema, a short thread.) The following description is based on our data and data obtained from previous studies $(1,5,12$, $13,17)$. Cells are flexible and helical; they are 0.2 to $0.3 \mu \mathrm{m}$ in diameter and 4 to $5 \mu \mathrm{m}$ long. One to two waves occur, and the irregular wavelengths of the spirochete cells range from 2 to 3 $\mu \mathrm{m}$. Ultrastructurally, the cells possess traits that are typical of spirochetes. They possess an outer envelope, a protoplasmic cylinder, and sheathed periplasmic flagella in a 1-2-1 arrangement. Cytoplasmic tubules have not been observed. Cells are motile and exhibit flexing, rotational, and translational movements at $30^{\circ} \mathrm{C}$. Cells stain negatively by Gram reaction. While cells are visible by dark-field or phase-contrast microscopy, they cannot be seen when bright-field microscopy is used.

Brevinema strains have unique single-base nucleotide signatures at positions $52 \cdot 359(\mathrm{G} \cdot \mathrm{C})$ and $783 \cdot 799(\mathrm{U} \cdot \mathrm{A})$ which differentiate them from other major spirochete phylogenetic groups. Brevinema andersonii CT11616 ${ }^{\mathrm{T}}$, FS47, and MV116 have a distinguishing $16 \mathrm{~S}$ rRNA sequence corresponding to positions 724 to 750 in E. coli (5'-GGCAGCUACCUAUGC UAAGAUUGACGC-3').

Brevinema andersonii is host associated. Strains have been isolated from blood and other tissues of short-tailed shrews (Blarina brevicauda) and white-footed mice (Peromyscus leucopus) and are infectious for laboratory mice and Syrian hamsters.

The type species is Brevinema andersonii.

Description of Brevinema andersonii sp. nov. Brevinema andersonii (an.der.so'ni.i. N.L. gen. n. andersonii, of Anderson, named for John F. Anderson, who first described the organ- 
ism). The characteristics of Brevinema andersonii are the same as the characteristics described above for the genus. Chemoorganotrophic. Microaerophilic and catalase negative. Growth occurs in modified BSK medium at an optimal growth temperature of 30 to $34^{\circ} \mathrm{C}$ and an optimal $\mathrm{pH}$ of 7.4 ; under these conditions the generation time is 11 to $14 \mathrm{~h}$. Does not grow at $25^{\circ} \mathrm{C}$. Exhibits the following enzyme activities: $\mathrm{C}_{4}, \mathrm{C}_{5}, \mathrm{C}_{6}, \mathrm{C}_{8}$, $\mathrm{C}_{9}$, and $\mathrm{C}_{10}$ esterases, $\mathrm{C}_{4}$ esterase lipase, alkaline phosphatase, acid phosphatase, and $\beta$-glucuronidase.

Designation of the type strain. The type strain of Brevinema andersonii is CT11616 (= ATCC 43811). This strain was isolated from tissues of a short-tailed shrew (Blarina brevicauda) captured in West Haven, Conn. (1). The G+C content of this organism is $34 \mathrm{~mol} \%$.

\section{ACKNOWLEDGMENTS}

We thank Myron Sasser (Microbial ID, Newark, Del.) for performing the fatty acid analysis and Rod Kuehn (University of Minnesota, Minneapolis, Minn.) for assistance with the electron microscopy. This work would not have been possible without the help of David Neitzel and Janet Jarnefeld of the Minnesota Metropolitan Mosquito Control Division, St. Paul. We thank Tim Leonard for preparing the artwork. Appreciation is expressed to Thomas MacAdoo (Virginia Polytechnic Institute, Blacksburg) for providing linguistic expertise essential for construction of names. Dee Smith and Julie Konop provided technical assistance.

This work was supported in part by Public Health Service grants DE-08303 and DE-10374 from the National Institutes of Dental Research to B.J.P, by grant AR 34744 from the National Institutes of Health to R.C.J., and by a grant from the James W. Wilke Fund for Natural History to D.L.D.

\section{REFERENCES}

1. Anderson, J. F., R. C. Johnson, L. A. Magnarelli, F. W. Hyde, and T. G. Andreadis. 1987. New infectious spirochete isolated from short-tailed shrews and white-footed mice. J. Clin. Microbiol. 25:1490-1494.

2. Anderson, J. F., and L. A. Magnarelli. 1992. Epizootiology of Lyme disease and methods of cultivating Borrelia burgdorferi. Ann. N.Y. Acad. Sci. 653:52-63

3. Blake, M. S., K. H. Johnston, G. J. Russell-Jones, and E. C. Gotschlich. 1984. A rapid, sensitive method for detection of alkaline phosphataseconjugated anti-antibody on Western blots. Anal. Biochem. 136:175-179.

4. Brosius, J., M. L. Palmer, P. J. Kennedy, and H. F. Noller. 1978. Complete nucleotide sequence of a 16S ribosomal RNA gene from Escherichia coli. Proc. Natl. Acad. Sci. USA 75:4801-4805.

5. Defosse, D. L., B. J. Paster, F. E. Dewhirst, G. J. Fraser, and R. C. Johnson. 1993. Brevinema andersonii gen. nov., sp. nov., a new infectious spirochete isolated from feral shrews and mice, abstr. R-12, p. 295. In Abstracts of the 93rd General Meeting of the American Society for Microbiology 1993. American Society for Microbiology, Washington, D.C.

6. Dewhirst, F. E., B. J. Paster, and P. L. Bright. 1989. Chromobacterium, Eikenella, Kingella, Neiserria, Simonsiella, and Vitreoscilla species comprise a major branch of the beta group Proteobacteria by $16 \mathrm{~S}$ ribosomal ribonucleic acid sequence comparison: transfer of Eikenella and Simonsiella to the family Neisseriaceae (emend.) Int. J. Syst. Bacteriol. 39:258-266.

7. Guilian, G. G., R. L. Moss, and M. Greaser. 1983. Improved methodology for analysis and quantitation of proteins on one-dimensional silver stained slab gels. Anal. Biochem. 129:277-287.

8. Hughes, C. A. N., C. B. Kodner, and R. C. Johnson. 1992. DNA analysis of $\mathrm{NCH}-1$, the first north central U.S. human Lyme disease isolate. J. Clin. Microbiol. 30:698-703.

9. Jukes, T. H., and C. R. Cantor. 1969. Evolution of protein molecules, p. 21-132. In H. N. Munro (ed.), Mammalian protein metabolism, vol. 3. Academic Press, Inc., New York.

10. Kumar, S., K. Tamura, and M. Nei. 1993. MEGA: molecular evolutionary genetic analysis, version 1.0. The Pennsylvania State University, University Park.

11. Lane, D. J., B. Pace, G. J. Olsen, D. A. Stahl, M. L. Sogin, and N. R. Pace. 1985. Rapid determination of 16 S ribosomal RNA sequences for phylogenetic analyses. Proc. Natl. Acad. Sci. USA 82:6955-6959.

12. LeFebvre, R. B., and G. C. Perng. 1989. Genetic and antigenic characterization of Borrelia coriaceae, putative agent of epizootic bovine abortion. J. Clin. Microbiol. 27:389-393.

13. LeFebvre, R. B., G. C. Perng, and R. C. Johnson. 1989. Characterization of Borrelia burgdorferi isolates by restriction endonuclease analysis and DNA hybridization. J. Clin. Microbiol. 27:636-639.

14. Marmur, J., and P. Doty. 1962. Determination of the base composition of deoxyribonucleic acid from its thermal denaturation temperature. J. Mol. Biol. 5:109-118.

15. Pace, B., E. A. Matthews, K. D. Johnson, C. R. Cantor, and N. R. Pace. 1982. Conserved 5S rRNA complement to tRNA is not required for protein synthesis. Proc. Natl. Acad. Sci. USA 79:36-40.

16. Paster, B. J., and F. E. Dewhirst. 1988. Phylogeny of campylobacters, wolinellas, Bacteroides gracilis, and Bacteroides ureolyticus by $16 \mathrm{~S}$ ribosomal ribonucleic acid sequencing. Int. J. Syst. Bacteriol. 38:56-62.

17. Paster, B. J., F. E. Dewhirst, W. G. Weisberg, L. A. Tardoff, G. J. Fraser, R. B. Hespell, T. B. Stanton, L. Zablen, L. Mandelco, and C. R. Woese. 1991. Phylogenetic analysis of the spirochetes. J. Bacteriol. 173:6101-6109.

18. Saitou, N., and M. Nei. 1987. The neighbor-joining method: a new method for reconstructing phylogenetic trees. Mol. Biol. Evol. 4:406-425.

19. Sasser, M., and M. D. Wichman. 1991. Identification of microorganisms through the use of gas chromatography and high-performance liquid chromatography, p. 111-118. In W. J. Hausler, Jr., K. L. Herrmann, H. D. Isenberg, and H. D. Shadomy (ed.), Manual of clinical microbiology, 5th ed. American Society for Microbiology, Washington, D.C.

20. Towbin, H., T. Staehelin, and J. Gordon. 1979. Electrophoretic transfer of proteins from polyacrylamide gels to nitrocellulose sheets: procedure and some applications. Proc. Natl. Acad. Sci. USA 76:4350-4354.

21. Weisburg, W. G., R. P. Hatch, and C. R. Woese. 1986. Eubacterial origin of the chlamydiae. J. Bacteriol, 167:570-574.

22. Woese, C. R. 1987. Bacterial evolution. Microbiol. Rev. 51:221-271. 